\title{
Santiago de Compostela: Aspects of a cult in Malta of the Knights of St John*
}

\author{
Santiago de Compostela: características de su culto \\ en la Malta de los Caballeros de San Juan
}

\author{
EMANUEL BUTTIGIEG \\ University of Malta \\ Faculty of Arts \\ Department of History \\ Msida MSD 2080 (Malta) \\ emanuel.buttigieg@um.edu.mt
}

iD

\section{Franco Davies}

Malta Historical Fencing Association (MHFA)

Independent Scholar

56/2 Triq I-Imћazen

Floriana FRN I I 5 (Malta)

franco.a.davies@gmail.com

(iD)

Abstract: The cult of St James within the Order of St John was evident throughout its stay in Malta in the architectural fabric it left behind, particularly the fortified land-front of the city of Valletta, as well as in other notable buildings, namely the Auberge of Castile, León and Portugal, and its church of St James. While its architectural aspects have withstood the test of time, other social aspects of the cult of Santiago in Malta are evident through the religious art in the Conventual Church of the Order in Valletta, today St John's co-cathedral, but also through religious rituals held on the island during the stay of the knights. This reflected a local cult which shows hints of being present also before the arrival of the Hospitaller Order to the Maltese shores.

Keywords: Military History. St James. Santiago de Compostela. Fortifications. Knights of St John. Valletta.

Resumen: El culto a Santiago en el seno de la Orden de San Juan quedó patente a lo largo de su estancia en Malta en el tejido arquitectónico que dejó tras de sí, en particular en la fachada fortificada de la ciudad de La Valeta, así como en otros edificios notables, a saber, el Albergue de Castilla, León y Portugal, y su iglesia de Santiago. Mientras que sus aspectos arquitectónicos han resistido la prueba del tiempo, otros aspectos sociales del culto a Santiago en Malta son evidentes a través del arte religioso en la Iglesia Conventual de la Orden en La Valeta, hoy concatedral de San Juan, pero también a través de los rituales religiosos celebrados en la isla durante la estancia de los caballeros. Esto refleja un culto local que muestra indicios de estar presente incluso antes de la llegada de la Orden Hospitalaria a las costas maltesas.

Palabras clave: Historia militar. Santiago. Santiago de Compostela. Fortificaciones. Caballeros de San Juan. La Valeta.

\footnotetext{
* We would like to acknowledge the assistance of these individuals who generously shared their expertise with us: Matthias Ebejer, Stephen Spiteri, Roger Vella Bonavita, Charles Dalli, Fra Luigi de Palma, Adrian Scerri, Daniel Gullo and Claudia Garradas.
}

MEMORIA Y CIVILIZACIÓN 24 (202I): 359-37I [I-I3] [ISSN: I I39-0I07; ISSN-e: 2254-6367] 
For just over 450 years, St James Cavalier, a solid, squarish structure has stood sentinel at the highest point of Malta's capital city, Valletta. Today referred to as Spazju Kreattiv (Maltese for Creative Space), it stands in one of Valletta's busiest areas, right across from the Office of the Prime Minister - formerly the Auberge of Castile, León and Portugal-, and close to the Central Bank of Malta, the Malta Stock Exchange, and the Parliament House, a reminder of the intimate, if not always harmonious ways in which culture, power and money have often rubbed shoulders. In the historical imagination of many Maltese, St James Cavalier is closely linked to one particular episode: 'the revolt of the priests' of 1775, the protagonist of which was the priest Dun Gaetano Mannarino'. On 9 September 1775, a small group of rebels managed to gain access to the Cavalier as part of a wider, but ultimately unsuccessful uprising. In a short period of time, the government of these islands, the Order of St John, was able to retake St James - and St Elmo, another fortress that had been occupied by the rebels- and the affair was over. In a sense, the Cavalier's role since 2000 as a centre for creativity echoes this episode, for it now witnesses a different form of 'drama' as hosts of creative entrepreneurs engage with audiences within the spaces of St James. In this manner, past and present, conflict and the arts, come together in making St James Cavalier a place where identity and heritage interact ${ }^{2}$. While possibly less obvious today, St James Cavalier was part of a 'Jacobean' landscape within early modern Valletta that stemmed from deep historic links with the Iberian Peninsula, and a vibrant cult of Santiago de Compostela in Malta.

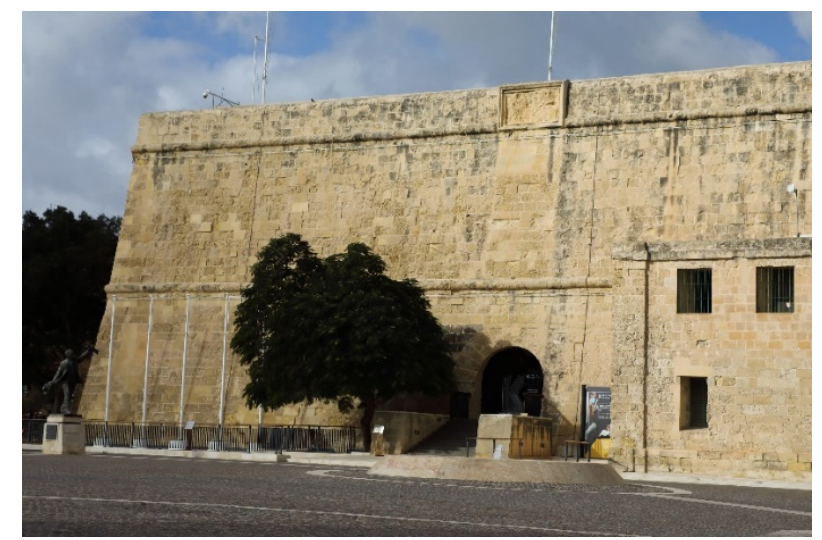

Figure I. St James Cavalier (photo: Christopher Cachia Zammit)

\footnotetext{
' Laspina, 1934, p. 100; Borg Muscat, 2002, pp. 239-252; Cassar and Vella, 2002; Bonello, 2009, pp. 99-1I5; Cassar, 2014; Meilak, 2015, pp. 21I-2I2.

2 England, 2005.
} 
The St James after which the Cavalier is named was one of the Apostles -in this context he is referred to as 'the Greater'-; he was, along with Peter and John -brother of James, traditionally considered to be the beloved disciple and later known as the Evangelist-, one of the three Apostles preferred by Jesus. Among the signs of favour James was - along with Peter and John - present at the Transfiguration of Jesus' ${ }^{3}$. James and John were called by Jesus the 'sons of thunder', a name that is taken to indicate their evangelical zeal and fiery temper ${ }^{4}$. According to the Legenda Aurea - a medieval collection of saints' lives-, following the Ascension of Jesus, James spent some time preaching in Judea and Samaria, before proceeding to Spain. Not meeting with much success in the evangelisation of the lberian lands, James returned to Jerusalem where around the year 42AD he was put to death by decapitation by King Herod Agrippa I. Hence, he became one of the first Christian martyrs. Tradition has it that his disciples carried his body to Galicia where they buried him in a forest. In the early ninth century his tomb was miraculously rediscovered and around this grew Santiago de Compostela, a major centre of Christian devotion and pilgrimage ${ }^{5}$.

The 'rediscovery' of the remains of St James happened in the charged context of the Reconquista, the stretched-out process through which the Christian powers of the northern fringes of Iberia gradually pushed out the Muslim forces, a process only completed in I492. Within the narrative of the Reconquista, various myths emerged describing the miraculous intervention of St James on a white horse during battles. The most renowned was the Battle of Clavijo in 844, where the saint's intervention was pivotal in granting victory to the Christian side 6 . Hence, St James came to have many manifestations: one of the favoured Apostles of Jesus, a pilgrim and protector of pilgrims, a martyr, a warrior-saint - Matamoros or moor slayer - and patron saint of Spain ${ }^{7}$. Like St George the dragon slayer, St James became the paradigm for the Christian knight and as such, devotion for him spread within the military-religious orders.

\footnotetext{
${ }^{3}$ Mark 9:2; Matthew 17:1; Luke 9:28.

${ }^{4}$ Camerlynck, 1910.

${ }^{5}$ For a seventeenth-century example see Guzmán, 2018.

${ }^{6}$ Giorgi, 2007, pp. 156-159.

${ }^{7}$ Kamen, 2008; Webster, 2019.
} 


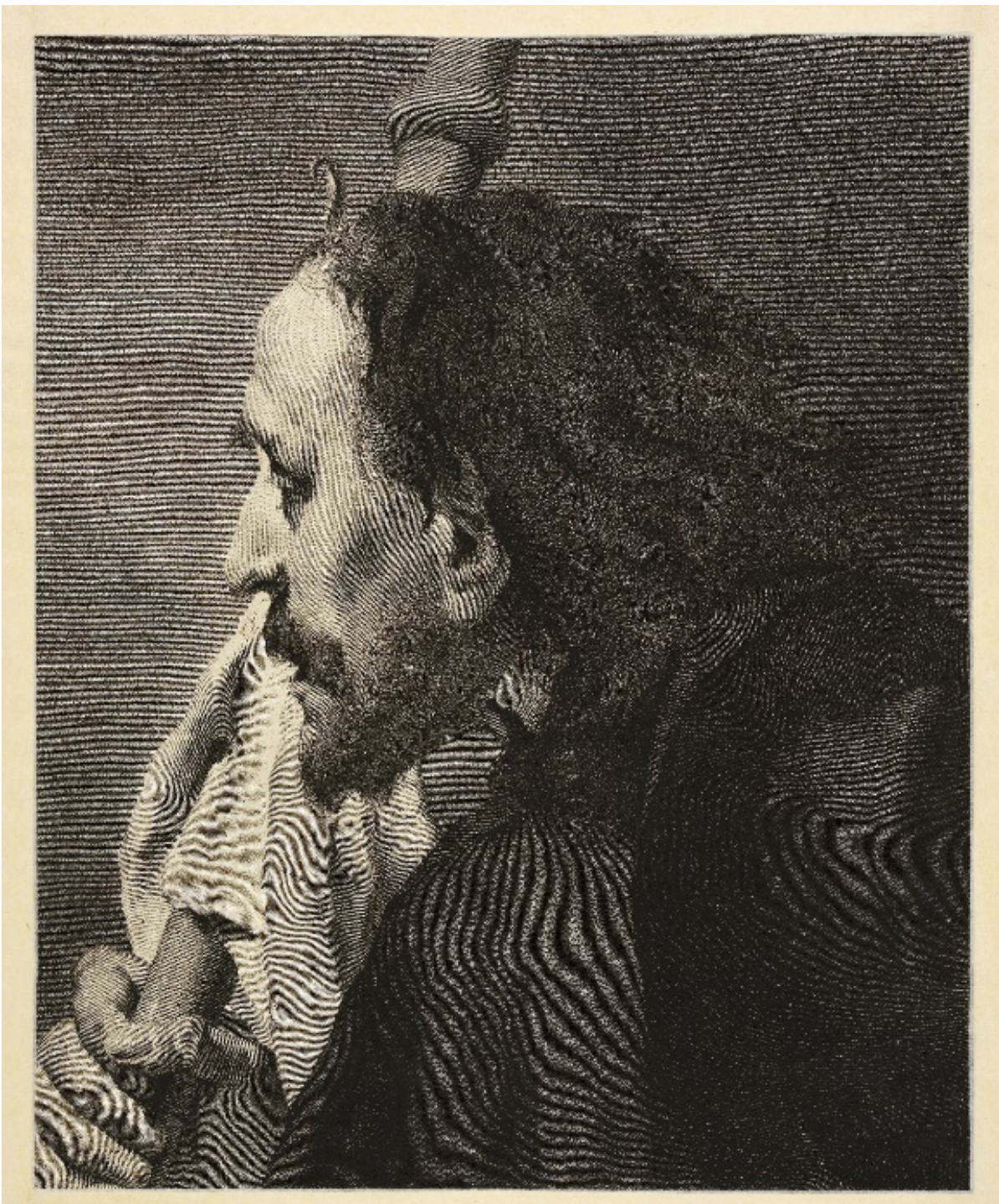

Figure 2. Giovanni Marco Pitteri, 'Sanctus Jacobus Maior', engraving, $38.8 \times 31 \mathrm{~cm}$, Saint James the Elder as a pilgrim showing his face in profile with a staff in his right hand, from the series of 'The Holy Family and Apostles' (Image courtesy of Mużew Nazzjonali tal-Arti, Heritage Malta, and the Malta Study Center at the Hill Museum and Manuscript Library).

There was a strong cult of St James within the Order of St John when this was in Malta, but evidence of interest in this saint on these islands predates their take-over by the Order in 1530. This may have been related to the link between 
Spain and Malta through an Aragonese presence as early as the thirteenth century. Some examples include a fresco possibly showing St James inside the fifteenth-century chapel of Hal Millieri ${ }^{8}$ and the chapel of Sancti Jacobi Apostoli Guedrum identified by the Apostolic Visitor to Malta Mgr Pietro Dusina in 1575. There was an altar at the Mdina Cathedral and a number of churches (including the Parish church at Rabat, Gozo) and chapels, all of which were in existence prior to the sixteenth century ${ }^{10}$. Moreover, the cult of St James among the populations of the Maltese islands continued to grow during the seventeenth century". Hence, interest in and devotion towards St James among the members of the Order (the Hospitallers) were mirrored in the wider cultic presence of the saint on these islands.

Given the stature of St James in the Christian tradition, it comes as no surprise that his name was assigned to particularly prominent military-architectural features. When the Order developed the fortifications of Birgu (the main maritime town of Malta before the development of Valletta) prior to the Ottoman Siege of 1565, the land front was protected by two key features: a bastion and cavalier of St John the Baptist and a bastion of St James (a cavalier dedicated to this saint was added after 1565, in the eighteenth century). The same pattern was repeated in the construction of the defences of Valletta where the land front was protected by four bastions, the central two of which had a cavalier dedicated to these two saints ${ }^{12}$. The cavaliers were 'the visible embodiment of a feeling of strength and confidence' ${ }^{13}$. Together, they constituted a powerful pair: St James, a 'son of thunder' and St John, precursor of Christ and patron saint of the Order ${ }^{14}$. From around 1763, St James Cavalier also began to serve as depository of weapons, second only to that found in the Palace of the Grand Master. Here, cannon, powder and small arms were kept for use, as well being a space where old weapons could be displayed in trophies or hung along the walls ${ }^{15}$. In 1757 , prisoners awaiting trial were moved to St James Cavalier while the Law Courts building (down the road from the Cavalier) was undergoing renovation works ${ }^{16}$.

\footnotetext{
8 Buhagiar, 1993, pp. 129-142; Vella, 2013, p. 150.

${ }^{9}$ Aquilina and Fiorini, 200I, p. 168; Borg, 2008, p. 226; Buhagiar, 2012, pp. 103-108.

${ }^{10}$ Borg, 2009, pp. 658-660.

1 'Borg, 2015, pp. 887-891.

12 Bosio, Dell'Istoria, 1602, pp. 744-745; Spiteri, 200I; Spiteri, 2008.

${ }^{13}$ Hughes, 2005, p. 42.

${ }^{14}$ Sciberras, 2009, pp. I 14-120; Buttigieg, 20I I, p. 109.

${ }^{15}$ Spiteri, 2013, pp. 120-121.

16 Testa, 1989, p. 24I.
} 


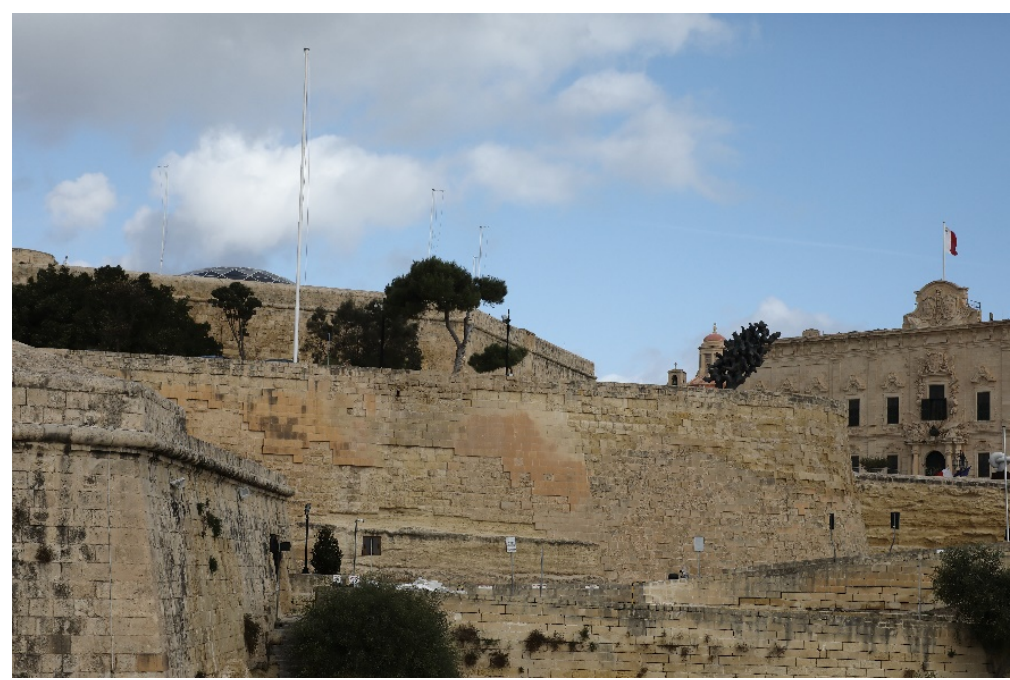

Figure 3. St James Bastion (centre) with St James Counterguard (on its left) and St James Cavalier (in the background). To the right of St James Cavalier can be seen part of the façade of the Auberge of Castile, León and Portugal, today the Office of the Prime Minister of Malta (photo: Christopher Cachia Zammit).

The cavalier to the right of the land front gate (by convention viewed from within the city) holds the most important position; hence its dedication to St John the Baptist by the Order which bore his name. The fact that the next most important position was given to St James is further affirmation of the high status enjoyed by St James among the Hospitallers. It was also a manifestation of the power and influence of Spain in the sixteenth-century Mediterranean world in general, and in the affairs of the Order in particular. The Mediterranean was the arena where a constant struggle between two great Empires - Spanish and Ottoman- unfolded ${ }^{17}$. In the East lay the Muslim Ottoman Empire under Suleyman the Magnificent (r. I520-1566), sprawling over the Balkan Peninsula, Asia Minor and most of the Arab world. In the West lay the Spanish, Habsburg and Catholic Empire under Charles V (r. 15I6-I556) and Philip II (r. I556-1598) ${ }^{18}$. Against this backdrop, Malta featured quite prominently on the Mediterranean stage being in effect a feudal possession of the Spanish vice-royalty of Sicily. Malta's position between Italy and Africa made it the object of dispute between Christians and Muslims, particularly as pressure intensified from both sides to assert effective control over North Africa over the course of the sixteenth century ${ }^{19}$. When the

\footnotetext{
${ }^{17}$ Brogini, 201 I, pp. 57-69.

${ }^{18}$ Braudel, 1972; Hernando Sánchez, 2000, pp. 21-91; Cutajar and Cassar, 2005, pp. I-34.

${ }^{19}$ Riley-Smith, 1999, p. 106.
} 
Ottomans laid siege to Malta in 1565 , the only power that could seriously help the Order was Spain. In fact, the chronicler of the siege, Francisco Balbi di Correggio recorded in his diary how there was an expectation among the Hospitaller-Maltese camp that the Spanish relief force would arrive on 25 July; this was because this was the feast day of St James, patron of Spain and because the viceroy of Sicily Don Garcia de Toledo was himself a member of the Order of St James $^{20}$. Alas for Balbi and the rest of the besieged, Spanish assistance would only arrive on 7 September.

It was not only in Birgu and Valletta that the Order dedicated features in the military landscape to St James. When the Order took over the Spanish fortress of Tripoli in North Africa in 1530, there was already a St James Bastion, which dedication the Order maintained. Later, when in the seventeenth century the Order developed a line of defences around the grand harbour known as the Cottonera lines (named after the Grand Master Nicolas Cotoner, who was from Mallorca), these included a St James curtain, bastion and gate ${ }^{21}$. By contrast, in Rhodes (the Hospitallers' home prior to Malta) no fortification seems to have been specifically dedicated to St James, although the walls of Rhodes town did have a Spanish sector and a bastion of Spain ${ }^{22}$. Perhaps Malta's feudal connections to Spain and geographical proximity to Spanish Sicily, along with the Spain's rise to prominence in the sixteenth century best explains Spanish influence on the Order ${ }^{23}$.

Furthermore, the Order of St John had a number of long-established connections to Santiago de Compostela, dating to well before I530. In Provençe, since the early twelfth century, the Order had an important seat in the town of Saint-Gilles, a nodal point of the pilgrim routes leading to Compostela. In Aragon, a grant at Atapuerca in I 126-27 initiated the Order's work of hospitality on the route to Compostela, along which it came to have a number of hospices. In Navarre, at the town of Puente la Reina, a Hospitaller nuns' priory developed, to which a pilgrims' hospital and a community of priests were added in the fifteenth century, providing another stopping-place to Compostela ${ }^{24}$.

The strength of the cult of St James in Malta under the Order of St John can be discerned in what may be termed a 'Jacobean' landscape in the top-left corner (viewed from the inside) of Valletta. It is important to note that St James

\footnotetext{
${ }^{20}$ Balbi di Correggio, The Siege of Malta, pp. 128-129; Vesco, 2015, pp. 223-230.

${ }^{21}$ Spiteri, 200I, pp. 290-299; Spiteri, 2008, p. 425.

22 Manoussou-Della, 200I, pp. 150-15I.

${ }^{23}$ Actas Primer Coloquio Internacional Hispano Maltés de Historia, 1991; Giuffrida, 2006; Ligresti, 2006; Abela, Buttigieg and Vassallo, 2015; Brunetti, 2016, pp. 733-770.

${ }^{24}$ Sire, 1994, pp. 117, 139, 144.
} 
Cavalier did not stand in isolation, but was part of a whole system: St James Ditch - St James Counterguard - St James Bastion - St James Cavalier-. It was a crescendo of power and might, culminating in the artillery platform on the top of the Cavalier, which was its most important element and one of the highest points in Valletta, giving it a commanding view of the city, harbour, and adjacent countryside. Linked to these four elements was the Auberge of Castile, León and Portugal, an Iberian ethnic enclave in Valletta with close religious-national links to the cult of St James.
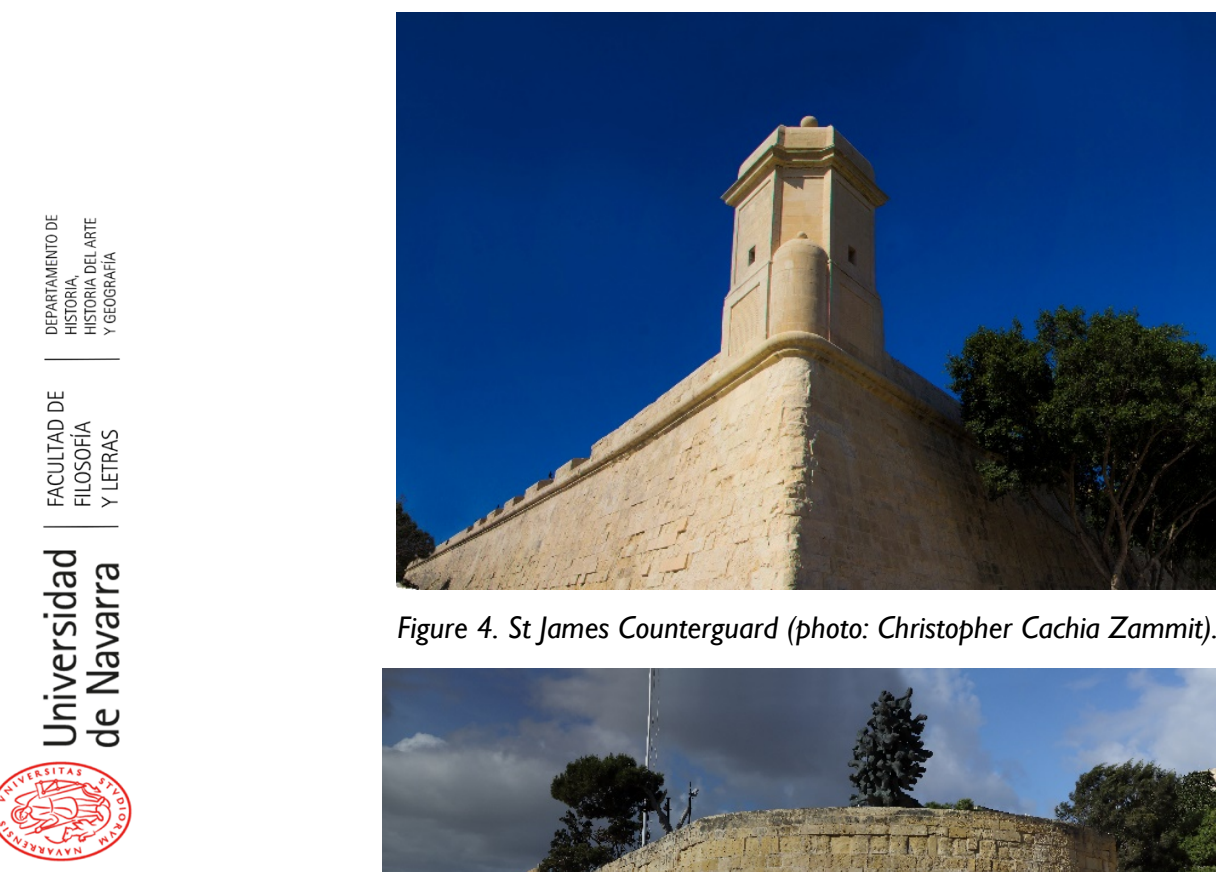

Figure 4. St James Counterguard (photo: Christopher Cachia Zammit).

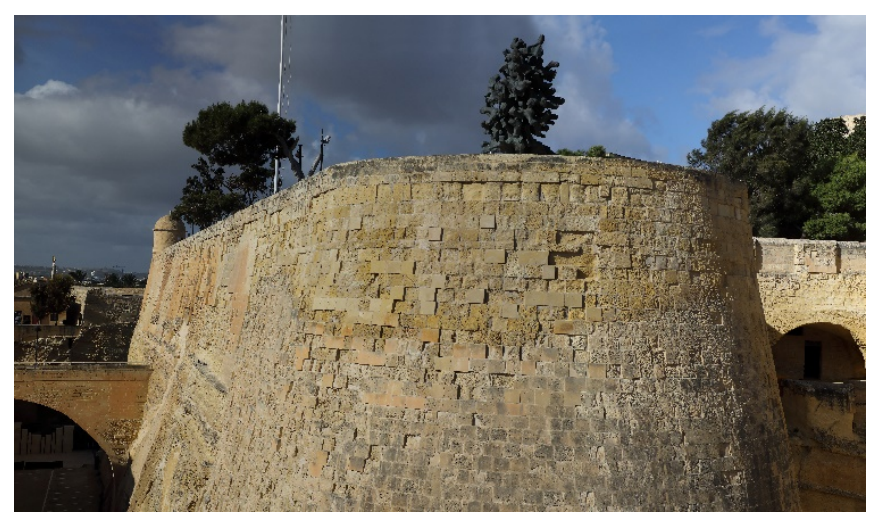

Figure 5. St James Bastion (photo: Christopher Cachia Zammit).

This Jacobean network of structures was extended further by the church of St James, just one block down from the Auberge of Castile, on the corner of Merchants' and Melita Street. Importantly, this was the church of the Auberge -and hence its dedication to St James - and it stood on one of the main arteries 
of Valletta. While today this is called Merchants' Street, originally it was in fact St James Street, and it ran all the length of the city ${ }^{25}$. The church of St James was rebuilt in 1710 - probably on a design by Romano Carapecchia - replacing an earlier church built in 1612. A striking element in the first church was the altar painting by Filippo Paladini showing St James receiving the revelation of his impending martyrdom ${ }^{26}$. Aside from depicting the martyrdom of St James, this painting also shows him holding the staff of the pilgrim, one of his other major hall marks.

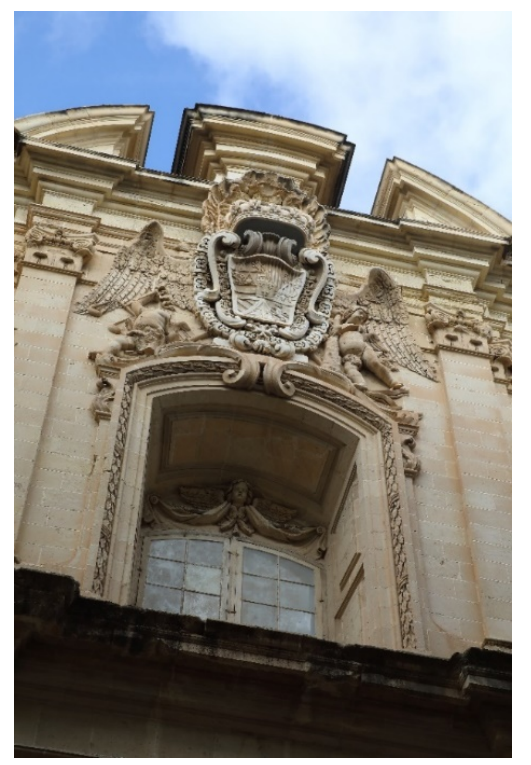

Figure 6. Detail from the façade of the Church of St James (photo: Christopher Cachia Zammit).

Just down the road from St James's Church —and acting like a satellite to this Jacobean constellation - the Conventual Church of St John the Baptist, the main church of the Order of St John, contains further evidence of the strength of the cult of St James and its popularity as an iconographical subject among Hospitallers. Inside St John's, the Langue of Castile, León and Portugal had their own chapel, dedicated to St James. Mattia Preti painted three works depicting scenes from the life of the saint: the altar-piece depicting a monumental St James as a pilgrim, and two lunettes facing each other, one showing 'St James and the Virgin of the Pillar' and the other 'St James defeating the Moors at Clavijo'; the serenity

\footnotetext{
${ }^{25}$ Galea, 20II, p. IX.

${ }^{26}$ Buhagiar, 2009, pp. 175- 179.
} 
of the former contrasting with the violence of the latter ${ }^{27}$. When, in 1760, he was describing this painting in a treatise about religious practices in St John's church, the chaplain of the Order Fra Ottavio Garcin made it a point to note how the Spanish sung the following verses in honour of the saint:

\section{Tu Bella Cum Nos Angerent \\ Es Visas Ipso in Proelio \\ Equoque et Ense Acerrimus \\ Mauras fuventes stermere ${ }^{28}$.}

The cult of St James was further enhanced through the presence of a relic of the saint: a small bone which was held in a silver reliquary in the shape of a scallop shell -a symbol specific to pilgrims going to Santiago- surrounded by stars. This relic had been brought to Malta from Rhodes ${ }^{29}$. On the feast day of St James - 25 July - a mass and procession were organised with this relic, which was taken to the Church of St James. It then returned in procession to St John's and was taken to the Chapel of St James. Such was the importance of this feast that the Grand Master himself participated ${ }^{30}$.

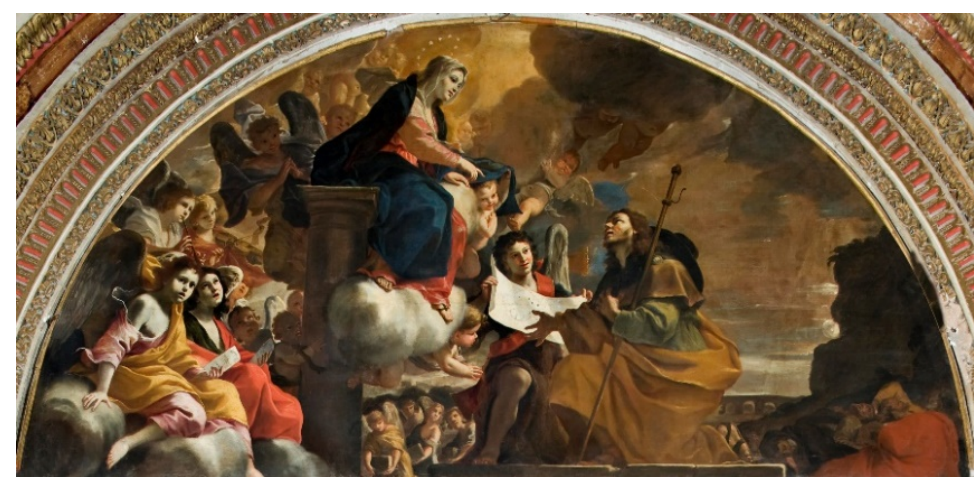

Figure 7. Mattia Preti, St James and the Virgin of the Pillar, oil on canvas, $259 \times 526 \mathrm{~cm}$, lunette, Chapel of the Langue of Castile, León and Portugal, St John's Co-Cathedral, Valletta - Malta (@) Copyright St. John's Co-Cathedral Foundation)

${ }^{27}$ Sciberras, 2009, pp. 126-129; Sciberras, 2020, pp. 153-155, 297, 301.

${ }^{28}$ National Library of Malta, Library Manuscript 27I, f. 126.

${ }^{29}$ National Library of Malta, Library Manuscript 27I, f. 26.

${ }^{30}$ National Library of Malta, Archive of the Order of Malta 1957; Scarabelli, 2004, p. 101. 


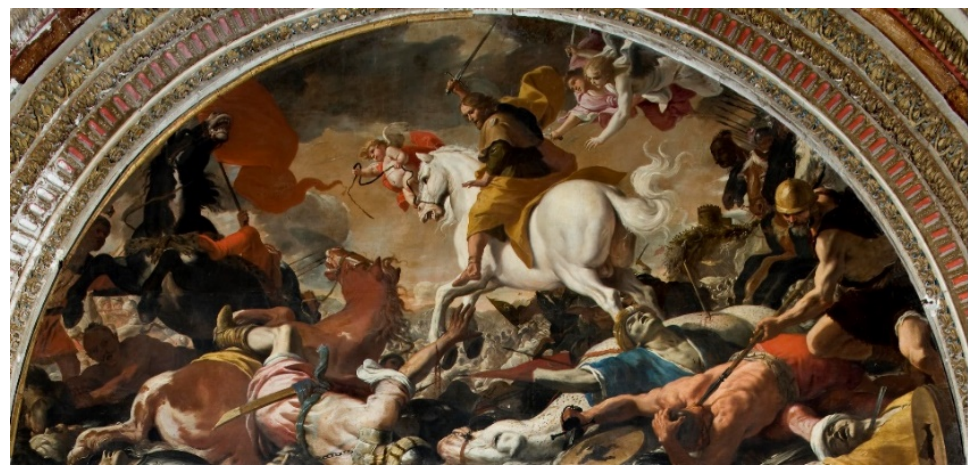

Figure 8. Mattia Preti, St James defeats the Moors at Clavijo, oil on canvas, 259x526cm, lunette, Chapel of the Langue of Castile, León and Portugal, St John's Co-Cathedral, Valletta - Malta (@ Copyright St. John's Co-Cathedral Foundation)
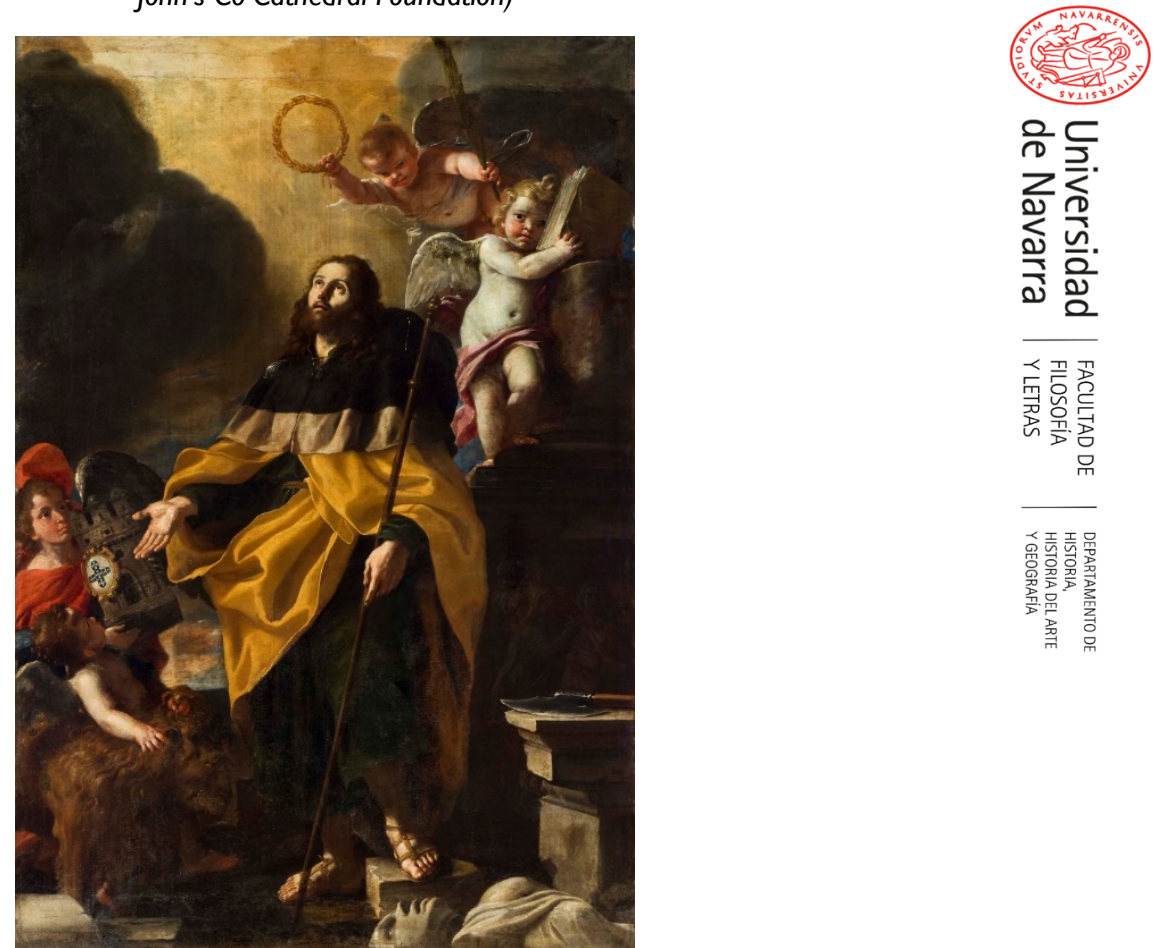

Figure 9. Mattia Preti, St James Major, oil on canvas, $306 \times 209 \mathrm{~cm}$, altarpiece of the Chapel of the Langue of Castile, León and Portugal, St John's Co-Cathedral, Valletta - Malta (@) Copyright St. John's Co-Cathedral Foundation)

James was an itinerant saint; in life he is considered to have travelled between the Holy Land and Spain, while after he died, his relics travelled to Spain. 


\section{EMANUEL BUTTIGIEG - FRANCO DAVIES}

Devotion towards him spread to all Christendom and he became the patron saint of pilgrims. The annual procession in Valletta with his relic recalled the many aspects of the saint's life and cult. Devotees could turn to St James for two issues in particular: to lend a helping hand with the affliction of rheumatism and to deal with the inconvenience of inclement weather ${ }^{31}$. One can imagine participants in the procession invoking the saint to help out with such matters. The procession with the relic served to consecrate and renew the Jacobean landscape of that part of the city, reconnecting it every year with the main church of the Order. Moreover, the movement of the relic between St John's Conventual Church and St James' Church could be seen as the spiritual equivalent to the two massive cavaliers guarding the entrance to Valletta, calling upon these two pillars of Christianity to safeguard the Order and its city. St James' manifestations as an Apostle, as a pilgrim, and as a warrior, were captured in early modern Valletta through ritual, canvas and stone.

\section{BIBLIOGRAPHY}

Abela, Joan, Emanuel Buttigieg and Carmel Vassallo (eds.), Proceedings of History Week 2013. Second Colloquium on Spanish-Maltese History, Malta, Malta Historical Society, 2013.

Actas Primer Coloquio Internacional Hispano Maltés de Historia, Madrid, Ministerio de Asuntos Exteriores, 1991.

Aquilina, George and Stanley Fiorini (eds.), Documentary Sources of Maltese History: Part IV - Documents at the Vatican. No. I- Archivio Secreto Vaticano Congregazione Vescovi e Regolari. Malta: Visita Apostolica no. 5 I Mgr Petrus Dusina, 1575, Msida, Malta University Press, 2001.

Bonello, Giovanni, Histories of Malta. Passions and Compassions. Volumen Ten, Valletta, Fondazzjoni Patrimonju Malti, 2009.

Borg Muscat, David, «Reassessing the September 1775 Rebellion: a Case of Lay Participation or a 'Rising of the Priests'?», Melita Historica, 13, 2, 2002, pp. 239-252.

Borg, Vincent, The Maltese Diocese and the Sicilian Environment from the Norman Period till I500 AD, Malta, Vincent Borg, 2008.

Borg, Vincent, The Maltese Diocese during the Sixteenth Century, Malta, Vincent Borg, 2009.

Borg, Vincent, The Maltese Diocese during the Seventeenth Century, Malta, Vincent Borg, 2015.

Bosio, Giacomo, Dell'Istoria della sacra religione et illma. Militia di San Giovanni Gierosolimitano. Parte Terza, Roma, Guglielmo Facciotto, 1602.

Balbi di Correggio, Francisco, The Siege of Malta 1565, ed. Ernle D. S. Bradford, London, Penguin Books, 2003.

Braudel, Fernand, The Mediterranean and the Mediterranean World in the Age of Philip II, New York, Harper and Row, 1972.

Brogini, Anne, «Sous le signe de la Croisade: La Valette, ville-frontière du XVle siècle», in Valletta. Città architettura e costruzione sotto il segno della fede e della guerra, ed. Nicoletta Marconi, Roma, Ist. Poligrafico dello Stato, 20II, pp. 57-69.

Brunetti, Oronzo, «Tra Pallade e Minerva: Le Fortificazioni nel Viceregno di Pedro De Toledo», in Rinascimento Meridionale: Napoli e il viceré Pedro de Toledo (1532-1553), ed. Encarnación Sánchez García, Napoli, Tullio Pironti editore, 2016, pp. 733-770.

Buhagiar, Keith, «Revisiting Wied ir-Rum: Some Recent Archaeological Discoveries», Melita Historica, I6, I, 2012, pp. 77-108.

Buhagiar, Mario, «The Fresco Cycle in the Church of the Annunciation at Hal Millieri, Malta: Some Iconographical and Historical Considerations», Melita Historica, II, 2, 1993, pp. 129-142.

${ }^{31}$ Giorgi, 2007, p. 156. 


\section{SANTIAGO DE COMPOSTELA: ASPECTS OF A CULT IN MALTA}

Buhagiar, Mario, Essays on the Knights and Art and Architecture in Malta 1500-I 798, Sta. Venera, Midsea Books, 2009.

Buttigieg, Emanuel, Nobility, Faith and Masculinity: The Hospitaller Knights of Malta, c. I580-c. I 700, London and New York, Continuum, 20II.

Camerlynck, Achille, «St. James the Greater», in The Catholic Encyclopedia, New York, Robert Appleton Company, 1910, volume 8, pp. 279-280.

Cassar, Dylan, Power through Knowledge. A Sociological Analysis of History Writing for Schools in Colonial Malta: The case of 'Outlines of Maltese History', Malta, University of Malta, 2014

Cassar, George and Yosanne Vella, The Evolution of History Pedagogy in Malta, Malta, History Teachers' Association, 2002.

Cutajar, Dominic and Carmel Cassar, «Malta and the Sixteenth-Century Struggle for the Mediterranean», in The Great Siege of Malta 1565: Separating Fact from Fiction, Valletta, Sacra Militia Foundation, 2005, PP. I-34.

England, Richard (ed.), St James Cavalier Centre for Creativity, Melfi, Casa Editrice Librìa, 2005.

Galea, Michael, Valletta: Statues, Niches, Small Churches, Public Fountains, Public Clocks, Monuments, Marble Tablets, Valletta, Allied Publications, 20II.

Giorgi, Rosa, Santi, Milan, Electa, 2007.

Giuffrida, Antonino, La Sicilia e l’Ordine di Malta (I529-I550). La centralita' della periferia mediterranea, Palermo, Associazione Mediterranea, 2006

Guzmán, Miguel Taín, A Medici Pilgrimage: The Devotional Journey of Cosimo III to Santiago de Compostela (I669), London, Harvey Miller Publishers, 2018.

Hernando Sánchez, Carlos José, «Saber y poder. La arquitectura militar en el reinado de Carlos V», in Las fortificaciones de Carlos V, ed. Carlos J. Hernando Sánchez, Madrid, Ediciones del Umbral, 2000, Pp. 21 91.

Hughes, Quentin, «An Architecture of Poetic Brilliance», in St James Cavalier Centre for Creativity, ed. Richard England, Melfi, Casa Editrice Librìa, 2005, pp. 4I-46.

Kamen, Henry, Imagining Spain: Historical myth and national identity, New Haven, Yale University Press, 2008.

Laspina, Salvatore, Outlines of Maltese History, Malta, Aquilina and Co., 1934

Ligresti, Domenico, Sicilia aperta (secoli XV-XVII) Mobilità di uomini e idee, Palermo, Associazione no profit Mediterranea, 2006

Manoussou-Della, Katerina, Medieval Town of Rhodes. Restoration Works (1985-2000), Rhodes, Ministry of Culture Greece, 200I.

Meilak, Daniel, Romantic Culture in Malta: A Historical Analysis, Msida, University of Malta, 2015.

Riley-Smith, Jonathan, Hospitallers: The History of the Order of St John, London, Hambledon Press, 1999.

Scarabelli, Giovanni, Culto e Devozione dei Cavalieri a Malta, Msida, Malta University Press, 2004.

Sciberras, Keith, Baroque Painting in Malta, Valletta, Midsea Books, 2009.

Sciberras, Keith, Mattia Preti. Life and Works, Valletta, Midsea Books, 2020.

Sire, Henry J. A., The Knights of Malta, New Haven and London, Yale University Press, 1994.

Spiteri, Stephen, Fortresses of the Knights, Hamrun, Book Distributors Limited, 200I.

Spiteri, Stephen, The Art of Fortress Building in Hospitaller Malta, 1530-I 798: A Study of Buildings Methods, Materials, and Techniques, San Gwann, Book Distributors Limited, 2008.

Spiteri, Stephen, Armoury of the Knights. A Study of the Palace Armoury, its Collection, \& the Military Storehouses of the Hospitaller Knights of the Order of St John, Valletta, Midsea Books, 2013.

Testa, Carmel, The Life and Times of Grand Master Pinto, I 74I-I 773, Valletta, Midsea Books, 1989.

Vella, Charlene, The Mediterranean Artistic Context of Late Medieval Malta, I09I-I530, Valletta, Midsea Books, 2013

Vesco, Maurizio, «Ingegneri militari nella Sicilia degli Asburgo: formazione, competenze e carriera di una figura professionale tra Cinque e Seicentoly, in Defensive Architecture of the Mediterranean. XV to XVIII Centuries. Vol. I, ed. Pablo Rodríguez-Navarro, Valencia, Editorial Universitat Politècnica de València, 20I5, pp. 223-230.

Webster, Jason, «St James and the Two Faces of Spain», History Today, October, 17, 2019 